\title{
$\square$ 特集論文 $\square$
}

\section{市町村条例に基づいた土地利用の規制・誘導手法の 類型化に関する考察}

A Study on the Types of Land Use Control by Ordinance

\section{池 邊このみ*}

Konomi IKEBE

\section{I 研究の背景と目的}

本研究が主体とする土地利用を対象とする规制 ・誘導については，国レベルの制度として，国土 利用計画法に基づく国土利用計画，各都道府県で 作成する土地利用基本計画，市町村が地方自治法 に基づいて作成する基本構想の土地利用計画部分 などがある。しかしながら、これらの計画におい ては，土地利用構想図などの目標像を示すに留ま るものが多く，规制・誘導の具体的方策として不 十分であった。そこで，市町村の多くは，開発行 為などの规制を目的として，宅地開発指導要網や まちつくくり条例などを独自に制定し，規制・誘導 を行ってきた。さらに，近年になっては自然環境 や景観の保全等を取り入れた市町村条例を制定す る市町村が增加しており，その内容も多粎化して いる。しかしながら，土地利用や自然環境を主体 とした条例では，規制・誘導の対象が，生物など を含む自然環境から建築物まで広範囲に及ぶこと や，私的財産権の問題もあり，その規制・誘導の 方針や根拠などを明確にしにくい状況にある。

平成 9 年に閣議決定された新総合土地政策推進 要網では，「それぞれの地域が個性を生かし，総 合的に土地利用を図ることを可能とするため，地 方分権の推進に関する動向を踏まえ，地方公共団 体における各種土地利用の調整や規制の基本とな る土地利用に関する計画のあり方について，中長 期的な視点にたって検討する」とある。また，今
後一層，市町村独自の条例制定が增加すると見ら れることからこれらの条例の規制・誘導力やそ の根拠をどこに求めるかなどについての研究が必 要とされている。従来, この種の研究対象におい ては，個別の事例研究1)や制度的な研究2)が主で あり，総体としての条例の種別や特性分析などの 研究は行われていない。これらのことから，本研 究は市町村条例を規制・誘導の観点から類型化し， その特性と課題を明らかにすることを目的に実施 したものである。

\section{III調查の方法と内容}

旧国土庁（現国土交通省）では，土地利用の市 町村における総合的な土地利用計画の整備・充実 の観点から，市町村に対するアンケート及びヒア リング調查などを経年的に行なってきた。平成 9 年には，全国の市町村に対して「市町村における 条例・要網の制定の実態把握についての調査」が なされており，平成10年には「市町村における条 例に基づいた土地利用規制・誘導に関する詳細調 查」平成11年には「景観・自然環境に関する観点 を取り入れた土地利用調整の実態調查」がそれぞ れ行われている。

本論では，それらの調査研究により収集された 市町村レベルにおける土地利用等の規制・誘導を 目的とする条例のうち，条例による規制・誘道の 方向性あるいはその根拠，また，環境の担保性が 明確なものを選択し，研究対象としている。

*(侏註信基磷研究所 STB Research Institute

Key Words：1) 土地利用，2）市町村条例，3) 規制・誘導，4）地域評価，5) 開発規制 
土地利用の規制・誘導を目的とする市町村条例 については，その対象とする分野や内容は多様で あり，条例の対象地域，規制·誘導の対象，また， その誘導の根拠となる地域評価の方法, 規制・誘 導方策の担保性などについては，それぞれいくつ かのタイプに分類が可能である。本論では，規制 ・誘導の観点から類型化を図り，類型毎の特徴と その課題の抽出を試みた。

\section{III 調査分析の結果}

\section{1 規制・誘道の方法とその担保性との関係}

规制・誘導の方法については，(1)目標方針提示 型，(2)規制指針提示型，(3)目標基準設定型(4)制限 基準設定型に分けられる。

(1)目標方針提示型

各ゾーンの土地利用の目標とその方針のみを定 め，その方針に基ついて建築行為や開発行為をコ ントロールしようとする目標方針提示型は，その 基準が明確でなく，規制力が弱いといえる。また， 方針は定性的な表現が中心であることから，住民 の土地利用に対する意向を反映しやすく，合意が 得られやすいという特徵をもつ。そのため，条例 レベルでは，方針のみを規定し，その後，時間を かけて施行細則や運用規定などのかたちで詳細な 内容を規定していく形態も見られる。

(2)规制指針設定型

この型式では，十津川村の環境条例のように， 「天然林等の伐採は極力控えるよう配慮する」 「周辺の景観と調和した構造とするよう配虑する」, 「良好な自然環境を有する地域及び貴重な生物が 生息する地域では，土地造成を極力行わないなど」 の地域の土地利用方針などに応じた配慮指針や規 制指針を示し，建築行為や開発行為を指針によっ て规制・誘導するものである。しかしながら、こ のタイプは定性的な指針にとどまり数値的な基準 等がないため，拘束力が弱い傾向にある。また， 住民や事業者のモラルにまかせられる傾向もある ことから，住民参加による計画づくりや協定など で，担保性の強化を図っている事例がみられる。 掛川市や伊賀市などでは，協定区域における協定 を結ぶ際に，住民と行政だけでなく，土地所有者
の 8 割の同意を定めており，担保性の強化を図っ ている。

\section{(3)目標基泍設定型}

この型式は，敷地に占める保全緑地の量（割合） や緑地の質などの確保水準，建設あるいは開発す る際の条件を示すなど, 各種建築行為や開発行為 に明確な基準を設定することで，規制・誘導をお こなうものである。これらについては，開発その ものを規制しているものではないが，自然環境の 豊かな地域では，保全目標が高く設定されており， 結果として事業者が意図するままの開発ができず, 結果として開発抑制として機能している。たとえ ば，逗子市では，自然環境を 4 つのランクに評価 しており，自然環境のランクの高いAランクの場 合には $80 \%$ 保全となり，事業者にとって開発その ものが難しい水準となっている。また，池田市の 「五月山条例」では「眺望権」の確保を目的とし た環境保全緑地の設定がされており，緑や自然環 境の保全という限られた範囲での条例に多く見ら れるタイプである。

(4)制限基準設定型

この型式は，建築物の立地や用途・規模を特定 し，制限するものである。用途を規制している例 として, 神戸市, 穂高町の条例がある。規制のレ ベルとしては,【立地可能】、【条件付き立地可能】, 【立地不可等】等となっている。一方, 規模の制 限としては, 多くの条例において, 開発の土地の 規模によって，形質を変更する【行為の届出を必 要とするものと】，【許可の手続きを要求するもの】 にわける形態をとっている。真鶴町では，「土地 利用規制規準」を定め, 町全域を11の地区にゾー ニングし，地区別の土地利用方針の他，建坪率， 容積率，建築物の用途制限，高さの最高限度、敷 地面積の最小限度，外観や色彩によって基準を設 定している。地区によっては, 壁面境界や道路境 界などについても定めており，届け出を要しない 一定限度以下の建物についてもこれらの規定に従 うことになっている。

特に, 土地利用やまちづくりの誘導を目的にし ている条例では，施設や土地利用の種類により規 制するタイプ，景観やまちづくりの場合には，建 築形態などについて規定するものタイプが多い傾 
向にある。これらの基準設定型は，籍密な運用が 可能であり，目指すべき土地利用やまちの姿を実 現化することが容易である。しかし，基準の設定 に関して, 客観性の碓保, 地域の独自性の反映な どに基づく，住民合意の形成など，条例制定まで の課題が多く，この形式での条例制定をしている 事例はまだ少ない。

条例制定地域において開発を行うにあたっては， 以下のような段階別の手続きが必要である。

【行政担当部署との事前相談・協識】

一【届出·申請の対象となるものについての届出・申誚】

一【行政や住民, 関係者との調整・協栈・萫査】

$\rightarrow$ 【指導・钓告や許認可】

一【事後報告や立ち入り調查, 守られていない場合の罚 則の道用】

また, 届出や申請の对象となる行為は以下の 2 つに大別される。

・開発の规模や質を規制・誘導して土地利用を 整序するもの

・土地利用の改変そのものを規制・誘導して土 地利用を整序するもの

この他に, 建物用途の変更に際しても届出が必 要な条例や土地に関する権利の移転等も对象とし ている条例の例などもある。これらの手続きの相 違に上る㻴境の担保性（拘束力）の強弱に着目す ると，以下のように分類が可能である。

(1)許認可型

一定の開発行為，建築行為に対して許可または 承認が必要な形式。この形式は，担保性が最も高 いといえ，望ましい土地利用の実現に向けた奻果 は高い。山梨県の贯観条例では，地区の性格によっ て, 許可と届出の区分をしており, 特別地区では 許可, その他の地区は届出と, 規制に強弱をつけ ている。この他にも「重点地区」「誘導促進地区」 などの名称で許可の必要な地区を定める事例が多 くみられる。

(2)協定締結型

一定規模以上の開発行為に関しては, 届出を必 要とし, 届出後, 事業者と行政,または, 事業者 と住民（近隣関係者）間で協定を結ぶ形式である。 許認可型よりは担保性は弱いが, 協定の締結によ $\eta$, 一定の拘束力の確保が可能なため届出指導型
より担保性が高いといえる。

(3)届出指導型

事前に届出を行い，行政の指導・助言等の内容 に沿って，計画を修正した上で住民及び関係者の 同意を得て, 開発行為や建築行為を行う形式であ る。望ましい土地利用の実現に向けては，住民や 事業者の良識に追うところが大きく，担保性は最 も弱いと考えられる。しかし，届出制度の中には， 事前協議, 説明会, あるいは公聴会を義務づけら れているものもあり，一概に担保性が弱いとはい えない。逗子市の条例のように届出に必要な書類 として，環境影锌評価春もしくはそれに近い精度 の調查資料の提出をもとめられるところも見受け られ拘束力の強いものも含まれる。一方，規制力 の低い条例では，着手や完了等に関しての報告， 届出，立ち入り検査を義務づけたり，守られない 場合の罰則として，嶶役及び買金，氏名（会社名） や针告内容等の公表などを位置づけている。また， それらの罰則規定は適用事例が少ないことから，

【開発に必要な町の協力の拒否】(真鶴町, 篠山 市）や【まちづくり資金等の納付】（伊賀町，掛 川市）など他の間接的な開発抑制策により対応し ている事例もみられる。

\section{2 規制・誘道を目的とした地域評価手法につい ての考察}

国土利用計画法に基づく土地利用計画では，一 定基準以上の景観・自然環境に関しては，個別規 制法により担保されているが，条例の対象地域を 客観的に評価し，そのレベルに応じた規制・誘導 を行っていこうとする意向のある市町村において は，その規制・誘導の目的にそった独自の地域評 価が行われている。地方自治体においては，住民 にとって重要性が高い景観や自然環境の価值や機 能を保全することが、条例制定の動機や目的となっ ている場合が多い。そのため, 各個別规制法単独 の对応ではなじみにくい複合的な環境保全の梘点 から，地域評価をおこなっている事例がみられる。 ここでは，これらの評価の指標及びその客観性か ら，2つに分類した。

様々な指標を総合的に解析・評価してゾーンを 区分する(1)環境機能解析型と，解析的な評価は行 
わず，水资源，累観など特定の環境要素の分布や 地域的掂がりを定性的にとらえてゾーンを区分す る(2)地域アイデンティティ尊重型である。

(1)㻴境機能解析型

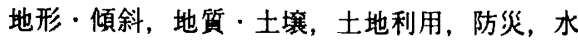
資源, 植生, 生態系, 法規制などの複数の指標を 土地の有する各種の複合的な機能として捕らえ， 点数化やランク化あるいは, オーバーレイ等の手 法により，総合的に解析・評価する方法である。 この手法では，土地の持つ多面的な機能に基づい た客観的な評価結果に基づきソーン区分を行い， それぞれの特性に合った土地利用の方向性を定め る方法をとっている。ここでは, これらの環境機 能解析型をさらに機能評価結果を数値化, 点数化 する「点数型」と、それぞれの機能毎にランク分 けを行い，オーバーレイなどの手法により総合化 して評価する「分級型」に分類した。点数型につ いては，影観・自然環境そのものを定量的に把握 する手法か確立されていないことや，評価にあたっ て多くの定量的な環境情報が必要なことから，探 用している自治体は少ない。

点数型の代表的な事例として，逗子市の「良好 な都市環境をつくる条例」がある。環境管理計画 を策定するにあたり，植生，地質，土地利用なと

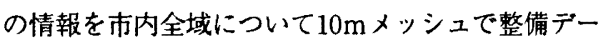
タベース化し, 開発などの土地利用に際し適切に 緑地を保全するためのアセスメント条例として制 定したものである。ここでは，各指標を機能別に 環境影響評価法により点数化し，その合計点数に より自然環境を4ランクに評価し，その評価ラン クにより㻴境保全目標を定める手法を探用してい る。

分級型は, 従来の地形, 土壤, 傾斜, 植生など の各種の環境指標について，それぞれ土地利用を 評価する複数の観点から，ランク付けをおこなう という従来の「土地分級」の手法により, 評価す るものである。

これらの数值型手法による評価結果を条例によ る規制・誘導方針策定に使用する場合には，指標 の収集やデータの解析に手間と時間を要すること から，既存の土地分級作業の結果や景観や自然環 境などについての調査結果を使用する場合もみら
れる。また，早急に規制・誘遵の必要とするとこ 万，既存調查を鑑み自然環境の豊かで保全などの 必要なところなどを先行的に評価し，【誘導促進 地域】などを設定する場合もある。

(2)地域アイデンティティ尊重型

地域の環境瓷源などを地域の持つ財産として取 り扱い，その分布などの調查結果や，地域資源に 対する住民アンケートなどによる評価結果を反映 する方法を本論では地域アイデンティティ尊重型 とした。この評価法においては, 学術性, 客観性 はかけるものの, 住民が地域環境に対してもつ愛 着や誇りなどが反映され，地域の独自性（地域に とって, 重要な場所, 植物, 動物, 詈観など) や 地域住民が共有する価值観（屋敷林やみんなで川 遊びをした川，代々守ってきた山林など）など, 希少性や学術的価値をもたなくても住民にとって 重要で保全意向のある環境などが高い評価を受け るという特蓖をもつ。しかしながら，環境機能解 析型に比べ客観性が確保できないため, 多くの市 町村では，審議会などを設置し，住民・行政の他， 学識経験者などを入れた委員組織で審議を行うこ とで，客観性を持たせている。

図 1 は，規制・誘導の強弱で分類した基準設定 による分類と担保性の強弱を示す手続きによる分 類の関係をみたものである。ここに評価手法によ る条例の分類をいれてみると, 環境機能解析型の 条例は，総じて客観性の高い評価手法を用いてお り, 特に规制・誘導力の強い制限基準設定型では 点数型を採用していること。一方, 地域アイデン ティテイ尊重型の条例は，方針や指針の規定に留 まっている傾向にあること。地域アイデンティティ 尊重型の採用は方針提示型から目標基準設定型で 多いことなどがわかる。また，担保性による分類 においては, 規制の比較的緩やかな届出指導型か ら協定締結型までは, 地域アイデンティティ尊重 型が多く採用され，許認可型では点数型が探用さ れる傾向にあることがわかった。

\section{3 規制・誘道の目的とその対象についての考察}

規制・誘導の目的は，地域の問題点の状況や条 例制定のねらいにより異なってくる。ここでは， 規制誘導の観点から，大きく 2 つに分類した。第 


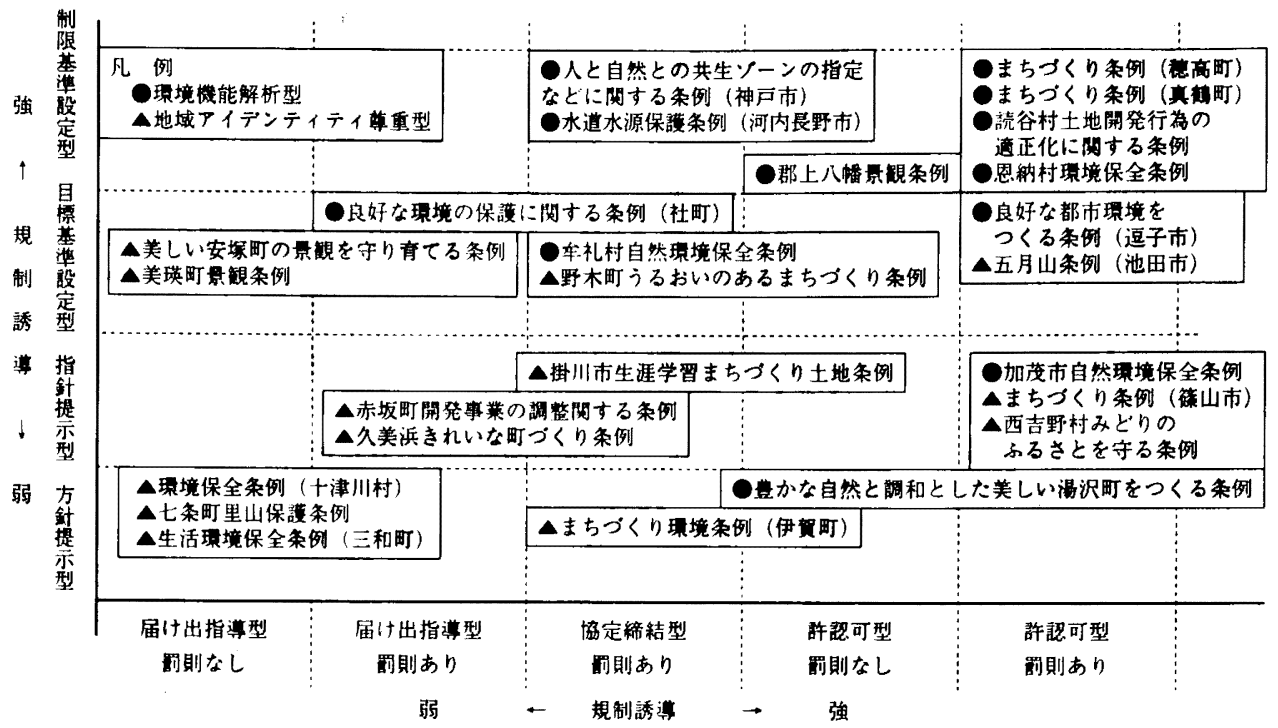

図 1 条例にみる規制・誘導の方法とその担保性の関係

1 は，現状の環境を維持するための開発抑制及び 保全を目的とするものであり，第 2 は地域の土地 利用などの目標像に従った方針や整備水準などを 定め, 誘導しようとするものである。前者は従来 の開発要網の流れを踏む条例に, 後者は市町村独 自の土地利用計画を策定している条例に多くみら れる形態である。

条例により規制・誘導される対象については， 土地利用，構築物，開発行為など多岐にわたる。 条例により保全される対象は，里山や森林また， その複合体としての景観等であるが，実際の規制 ·誘導の対象となるのは，土地利用そのものや土 地の形質の改変や建築物の建設をともなう一団の 開発行為, 建築物, 水源涵盖林やため池，林野な どに生息する生物を含めた複合的な土地利用形態 となる。

規制・誘導にあたって問題となるのは，第一に 基本的な土地利用 (都市的利用, 農業的利用など) に変化が生じるのかどうか, 次に土地利用として は，変化しない場合でも，例えば，人工林と自然 林，戸建住宅と集合住宅，工業用途と商業用途な どでは，自然環境などに与える影響が異なること から，どのような土地利用形態や環境であるのか
等が問題となる。さらに, 開発行為などで, 構造 物が設置される場合などには，これらの建築形態 や色彩などが景観などに影響を与える。これらの ことから，規制・誘導の対象は，開発行為などを 想定した環境改変という観点から以下の 4 つとし た。

(1)土地利用……都市地域, 森林地域, 農業地域 など土地利用基本計画に準ずる基碳的な土地 利用

(2)土地利用形態とその環境……植生・土壤等を 含む土地利用形態とその形態によって形成さ れる生物生態系や水资源, 鉱物資源等

(3)建筑物の用途……建築物の利用目的

(4)建築形態……建築物の立地形態と色彩，素材 などを含む建築形態

これらの規制・誘導対象の分類は, 前述した規 制・誘導の目的と各市町村のもつ土地利用上の課 題, どの程度の規制・誘導を行う必要性があるか などの状況によって異なり，複合したかたちで規 制・誘導の対象となっている。土地利用方針など 地域の将来的な方向性を定めることを目的とした 条例では(1)土地利用(3)建築物の用途, 累観の観点 では(2)土地利用形態と環境(4)建築形態，自然環境 
保全等では(2)土地利用形態と環境(3)建築物の用途 などが規制・誘導対象となっている場合が多い。

\section{4 規制誘導と対象地域についての考察}

市町村条例であることから，原則，市町村全域 を対象としたものが主流であるが，実際の規制 . 誘導はそのうちの計画白地地域（土地利用計画上 の 5 地域で，個別規制法の拘束力の強い地域を除 (地域), あるいは，市街化調整区域のみなどの 場合がみられる。また，行政区域をいくつかにゾー ン分けし，そのうちの特定区域のみを誘導対象と している条例も見受けられる。さらに，行政区域 の中から，あらかじめ規制・誘導対象となる地域 を設定し，その地域だけが対象地域となっている ものもあり，以下のように分類される。

(1)行政区域全域……域全体についてなんらかの 規制誘導方針のあるもの

(2)特定地域……条例制定目的にあった地域エリア のみが誘導区域であるもの

i）市街化調整区域

ii）計画白地地域

iii）条例の目的上, 誘導の必要な地域

iv）保全対象となる特定の対象が生息あるいは 存在する地域など

行政区域の全域については，コントロールすべ き問題が行政区域の全域で同じように発生してい る，または，発生する可能性がある場合に有効で ある。また，市町村の全域が都市計画区域外ある いは末線引きなど，土地利用規制の必要なレベル が同程度の場合や地域全域を同一の考え方に基つ いて規制・誘導する場合にも有効である。

特定地域型は, 神戸市の「人と自然との共生ゾー ンの指定等に関する条例」や八幡町の「郡上八幡 景観条例」のように, 市街化調整区域の土地利用 コントロール，都市計画区域内の景観形成，里山 の環境保全など，特定の課題を対象としている場 合に多く見られる。この型式ではあらかじめ関連 する地域を絞り込んだ場合は, 一部地域だけの評 価・検討を行うこととなり，計画に地域性を反映 しやすいといった利点がある。しかし大半は，行 政区域全域を評価し地区の絞り込みは行わない場 合が多い。また，対象範囲の指定の根赵やその区
域境界についても客観性が欠ける傾向にある。

地域エリアを対象としたもの以外では，熊本県 七城町の「七城町里山条例」「福岡県春日町の 「溜池条例」などがある。これらの条例は，その 対象を「里山：町内すべてに散在する林, 池沼」 あるいは, 「溜池及び溜池の満水面表面から水平 距離10メートル筙囲内の自然環境」としている。 また，大阪府池田市の「五月山条例」のように， 五月山の眺望権を守ることを目的としているため， 特定地域の山槐部分だけを対象としている条例も ある。またここでは対象としなかったが，ホ夕 ルやトンボなどの昆虫類やサンショウウオ, 鳥類 の生息環境の保全を目的とした条例策定もみられ， これらの条例では生息域を対象としているものも みられる。

\section{IV まとめ}

以上，市町村条例について，規制・誘導の観点 から類型化を試みた。規制・誘導の方法とその担 保性について, 地域の評価手法との関係をみてみ ると，数値による評価など客観的な地域評価結果 にもとづく条例に扔いては，規制・誘導の規定， 罰則などともに簃しく運用されていること。一方， 地域アイデンティティ尊重型とした地域独自の環 境評価を行った場合には，定性的な方針提示に留 まり，担保力も低い傾向にあることがわかった。

しかしながら，市町村条例は，開発計画の目白 押しであった時代には，開発抑制型のものが主流 であり, 開発指導要綱の域をでないものが多かっ た。しかし，近年においては地域独自の視点によ る環境保全の観点へと移行しつつあり，その多く は，住民自らが地域環境の評価を行い，その保全 のあり方を模索するものとなっている。また，住 民意向を反映した地域の土地利用の将来像を描く 計画策定事業なども推進されている。これらのこ とから, 今後は, いわゆる行政の指導としての規 制・誘導に頼るのではなく，住民の手で地域の将 来像を描き，環境を担保していく時代となること が手想される。今後，一層，これらの条例や条例 策定のための地域評価手法についての研究が必要 とされると同時に，制定過程や運用にあたっての 
住民の義務や貴任についても大きな研究課題とな ると思われる。

\section{捕注}

1）和多治（1999）「地方分権時代のまちづくり条例」

2) 和多治 (2000) 市街化区域内緑地における開発協 議と緑地保全に閲する研究第35回日本都市計画 学会学術論文集

3）柴田祐也（2000）田園地域における土地利用目標 像の設定とその実現のための課題に関す万研究 第35回日本都市計画学会学術踰文集
4 ）内海麻利（2000）地方分権に対応した委任条例と 自主条例との一体的な運用に関する研究 第35回 日本都市計画学会学術論文集

\section{参考文献}

1）国土庁（1997）市町村における総合的な土地利用 計画の整備充実に関する調查研究

2）国土庁（1999）市町村における条例に基づいた土 地利用规制・敦導に関する詳細調查

3）国土庁（2000）累観・自然環境に関する観点を取 ク入れた土地利用調整の実態調查

With regard to control and guidance for land use that are regulated by municipal ordinances, in keeping with the current age of decentralization, a change can be seen from those ordinances strongly characterized by development guidelines, as was observed in the past, to those uniquely formed by evaluating the current status of the region, establishing a future concept and enforcing control and guidelines based on guiding principles and standards to be applied to such ordinances. In this study, an attempt was made to typify municipal ordinances from the above aspect. As a result, it was possible to observe a correlation between the type of ordinances applying the regional valuation method and the type of ordinances taking the enforcement approach from the perspective of type of land use control

Key Word : 1) Land Use, 2) ordinance, 3) control, 4) regional valuation method, 5) development guidelines

(2001年 5 月18日 受理) 